\title{
GIBBERELLIC ACID EFFECT ON GROWTH AND FLOWERING OF AJANIA PACIFICA /NAKAI/BREMER ET HUMPHRIES
}

\author{
Małgorzata ZALEWSKA*, Małgorzata ANTKOWIAK \\ Department of Ornamental Plants and Vegetable Crops \\ University of Technology and Life Sciences in Bydgoszcz \\ Bernardynska 6/8, 85-029 Bydgoszcz, Poland
}

Received: March 20, 2013; Accepted: June 28, 2013

\begin{abstract}
The research addressed the effect of gibberellic acid $\left(\mathrm{GA}_{3}\right)$ on growth and flowering of Ajania pacifica /Nakai/ Bremer et Humphries 'Bea'. The vegetative growth lasted for 8 weeks in glasshouse, under natural long day and from August 15 - under natural short day. The plants were divided into four groups: 1 - the plants sprayed with distilled water (control combination); 2, 3 and 4 - the plants sprayed with $\mathrm{GA}_{3}$ ones, twice and thrice, respectively, starting from the $5^{\text {th }}$ week of growth, and then in the $6^{\text {th }}$ and $7^{\text {th }}$ week, successively. Each of the group was divided into two subgroups: the first one treated with $\mathrm{GA}_{3}$ at concentration of $250 \mathrm{mg} \cdot \mathrm{dm}^{-3}$ and the second with $500 \mathrm{mg} \cdot \mathrm{dm}^{-3}$. It was observed that double spraying with $\mathrm{GA}_{3}$ accelerated the buds development of Ajania pacifica, thus shortened the cultivation time by about two days. Treatment with $\mathrm{GA}_{3}$ at concentration $500 \mathrm{mg} \cdot \mathrm{dm}^{-3}$ stimulated the elongation of shoots more than treatment with $\mathrm{GA}_{3}$ at $250 \mathrm{mg} \cdot \mathrm{dm}^{-3}$. The plants sprayed twice were longer than the control and then those sprayed one time. However, elongation of shoots was not remarkable; corymbs were shorter, narrower, and contained lesser number of inflorescences. The present study indicates the specificity of the response of Ajania pacifica to $\mathrm{GA}_{3}$ treatment, which appears to be different from other ornamental species.
\end{abstract}

Key words: Ajania pacifica, elongation growth, $\mathrm{GA}_{3}$, flowering

\section{INTRODUCTION}

The genus Ajania covers more than 30 species (Erhardt et al. 2008). The group includes both the plants demonstrating valuable pharmacological properties, including specific substances used in traditional Chinese medicine (Meng et al. 2001) and those appreciated for their decorative value, used by horticulturalists and breeders. Ajania pacifica has originated from Central and Eastern Asia. It represents the family Asteraceae, the same as chrysanthemums, thus similar growing technology can be applied. Formerly it was known as Dendranthema pacificum and earlier as Chrysanthemum pacificum. The relationship between genus Chrysanthemum and Ajania is difficult to define. Hong-Bo et al. (2010) speculate that the discrep- ancy between them was recorded quite recently and some plants of Ajania can be more or less similar to Chrysanthemum. Their genetic closeness is seen e.g. on the results of the research on breeding intergenus hybrids (Zhao et al. 2008).

Ajania is a perennial. It differs from chrysanthemums by its small, disc-in-shape inflorescences, growing in corymbs. Flowers of some cultivars are tubular; others have additionally ligulate florets of the same or different colour, distributed on the margin of the inflorescence's head. The inflorescence formation stage is long lasting. They are located on straight rigid stem, which makes the plants a very shapely and durable product. The leaves grow on them alternately, similarly as in chrysanthemums. They are usually longitudinal, jagged in its upper part, wedged at the base. 
Upper sides of leaves are green, with well-marked whitish-silver borders, while undersides are covered with whitish-silver coating, which determines a decorative value of plants. The phase of the vegetative growth of plants took 8 weeks in the glasshouse, exposed to natural long day of $18 / 17$ hours in June/July.

Ajania attracts much interest today, both among the flower producers and the buyers. It shows a strong photoperiodic reaction. In natural conditions Ajania is flowering in autumn, but cultivation can be controlled by applying darkening for shortening the day to 10 hours. The plant is easy to grow. The cuttings get rooted very fast during 10-14 days. It can be also easily propagated in vitro (Zalewska et al. 2012). In general, it is offered as a pot plant but some cultivars are also used as cut flowers.

The aim of the study presented was to evaluate the effect of $\mathrm{GA}_{3}$ on the growth and development of Ajania pacifica cultivated in autumn under natural photoperiod for flowering.

\section{MATERIAL AND METHODS}

The research was conducted from June 17 to November 2, 2010, using Ajania pacifica /Nakai/ Bremer et Humphries 'Bea' cultivar. The 7-8 cm long cuttings from parent plant were rooted in peat substrate Florabalt Plus Semi 1 ( $\mathrm{pH}$ 6.0), in plastic pallets with $3 \mathrm{~cm}$ in diameter openings on June 17 . The rooted plants were divided into four groups: 1 (control combination) - the plants sprayed with distilled water, while plants in groups 2,3 and 4 were sprayed with solution of gibberellic acid $\left(\mathrm{GA}_{3}\right)$ one time, two times or three times respectively. Each group was divided into two subgroups: the first one was treated with $\mathrm{GA}_{3}$ at concentration of $250 \mathrm{mg} \cdot \mathrm{dm}^{-3}$ and the second one with $\mathrm{GA}_{3}$ at concentration of $500 \mathrm{mg} \cdot \mathrm{dm}^{-3}$. The first spray was done on July 15 (the fifth week of growth), then successively in the sixth and seventh week. On July 29, after six weeks of growth, the plants were replanted onto tables $25 \mathrm{~cm}$ deep, filled with peat substrate Florabalt Plus PV 1, pH 6.0, at the density of 100 plants $\cdot \mathrm{m}^{-2}$. Starting from August 15, the plants were grown under natural short day (less than 16 hours), which initiated the generative phase. During the phase of vegetative growth the temperature was $25.8 / 24.3^{\circ} \mathrm{C}$ and during the generative phase $20.2 / 19.5^{\circ} \mathrm{C}$, respectively.

The experiment was set up in randomized block design. Each experimental combination consisted of 16 plants; 4 replication $\times 4$ plants. The following dates were recorded: the appearance of the inflorescence bud, when it was well visible with the naked eye, beginning of flowering when in a half of the buds the first coloured flowers were visible and full flowering when a half of the inflorescences were in full bloom. For presentation in the tables, weighted means were calculated from these dates. The number of days from the beginning of short days until the appearance of the inflorescence buds at microscopic stage of development and the number of days starting from bud emergence to the beginning of flowering (macroscopic stage development), as well as the period of cultivation (from the start of short days to the beginning of flowering) were calculated. The length of main shoot, measured from the ground to topreaching inflorescence; width of the plant, which was the mean of the measurements of two widest dimensions of the plant; the length of the corymb, from the lowest inflorescence peduncles to the inflorescence top, as well as the corymb width, which also included the means of the measurements of two widest places were determined at the stage of full flowering. The number of peduncles of the corymb and the number of inflorescences at full flowering and buds at the early stages of flowering and unstained buds were determined.

The results of morphological traits measurements were subjected to analysis of variance and the significance of the differences across means were defined using Tukey's test at significance level of $\mathrm{p}=0.05$. The calculation involving the use of FR-ANALWAR software was based on Microsoft Excel (Rudnicki 2011).

\section{RESULTS}

In each experimental combination, $100 \%$ of the plants flowered, irrespective of the $\mathrm{GA}_{3}$ concentration and the number of sprays applied. The inflorescence buds started to appear in the first half 
Table 1. Time of inflorescence bud development stages (dates), depending on the concentration of $\mathrm{GA}_{3}$ and the number of $\mathrm{GA}_{3}$ applications

\begin{tabular}{|c|c|c|c|c|}
\hline $\begin{array}{c}\text { Concentration of } \mathrm{GA}_{3} \\
\text { (A) }\end{array}$ & $\begin{array}{l}\text { Number of } \mathrm{GA}_{3} \\
\text { applications }(\mathrm{B})\end{array}$ & $\begin{array}{l}\text { Inflorescence } \\
\text { bud visible }\end{array}$ & $\begin{array}{l}\text { Beginning } \\
\text { of flowering }\end{array}$ & Full flowering \\
\hline \multirow{5}{*}{$250 \mathrm{mg} \cdot \mathrm{dm}^{-3}$} & $\mathrm{C}^{*}$ & 13.09. & 22.10. & 02.11. \\
\hline & $1 x$ & 14.09 . & 21.10 . & 02.11 . \\
\hline & $2 x$ & 14.09. & 20.10 & 01.11. \\
\hline & $3 x$ & 14.09. & 23.10 . & 31.10 . \\
\hline & mean for $\mathrm{A}$ & 14.09. & 22.10 . & 01.11. \\
\hline \multirow{5}{*}{$500 \mathrm{mg} \cdot \mathrm{dm}^{-3}$} & $\mathrm{C}$ & 14.09. & 23.10 . & 01.11. \\
\hline & $1 x$ & 14.09. & 23.10 . & 01.11. \\
\hline & $2 \mathrm{x}$ & 14.09 . & 21.10. & 31.10. \\
\hline & $3 x$ & 14.09. & 21.10 . & 31.10 . \\
\hline & mean for $\mathrm{A}$ & 14.09. & 22.10. & 01.11. \\
\hline \multirow{4}{*}{ Mean for B } & $\mathrm{C}$ & 13.09. & 22.10 . & 02.11. \\
\hline & $1 \mathrm{x}$ & 14.09. & 22.10 . & 02.11. \\
\hline & $2 x$ & 14.09. & 20.10 . & 01.11. \\
\hline & $3 x$ & 14.09. & 22.10 . & 31.10 . \\
\hline
\end{tabular}

* C - control, the plants sprayed with distilled water, $1 \mathrm{x}$ - plants sprayed with $\mathrm{GA}_{3}$ once, $2 \mathrm{x}$ - plants sprayed with $\mathrm{GA}_{3}$ twice, $3 \mathrm{x}$ - plants sprayed with $\mathrm{GA}_{3}$ three times; n.s. - non-significant for $\mathrm{p}=0.05$

Table 2. Time of the microscopic and macroscopic development of the inflorescence buds and period of cultivation (days), depending on the concentration of $\mathrm{GA}_{3}$ and the number of $\mathrm{GA}_{3}$ applications

\begin{tabular}{|c|c|c|c|c|}
\hline Concentration of $\mathrm{GA}_{3}(\mathrm{~A})$ & $\begin{array}{l}\text { Number of } \mathrm{GA}_{3} \\
\text { applications (B) }\end{array}$ & $\begin{array}{l}\text { Microscopic } \\
\text { development }\end{array}$ & $\begin{array}{l}\text { Macroscopic } \\
\text { development }\end{array}$ & $\begin{array}{c}\text { Period } \\
\text { of cultivation }\end{array}$ \\
\hline \multirow{5}{*}{$250 \mathrm{mg} \cdot \mathrm{dm}^{-3}$} & $\mathrm{C}^{*}$ & 28.8 & 39.4 & 82.1 \\
\hline & $1 x$ & 29.9 & 36.8 & 80.6 \\
\hline & $2 \mathrm{x}$ & 30.0 & 36.4 & 80.4 \\
\hline & $3 x$ & 30.4 & 38.4 & 81.2 \\
\hline & mean for $\mathrm{A}$ & 29.8 & 37.8 & 81.1 \\
\hline \multirow{5}{*}{$500 \mathrm{mg} \cdot \mathrm{dm}^{-3}$} & $\mathrm{C}$ & 30.2 & 39.1 & 82.9 \\
\hline & $1 x$ & 30.0 & 38.6 & 82.6 \\
\hline & $2 \mathrm{x}$ & 29.8 & 36.8 & 81.1 \\
\hline & $3 x$ & 30.1 & 37.2 & 81.1 \\
\hline & mean for $\mathrm{A}$ & 30.0 & 37.9 & 81.9 \\
\hline \multirow{4}{*}{ Mean for B } & $\mathrm{C}$ & 29.5 & 39.2 & 82.5 \\
\hline & $1 x$ & 30.0 & 37.7 & 81.6 \\
\hline & $2 \mathrm{x}$ & 30.0 & 36.7 & 80.8 \\
\hline & $3 x$ & 30.2 & 37.8 & 81.2 \\
\hline \multirow{4}{*}{$\operatorname{LSD}_{0.05}$} & & $A=$ n.s. $*$ & $\mathrm{~A}=\mathrm{n} . \mathrm{s}$. & $A=0.73$ \\
\hline & & $\mathrm{B}=\mathrm{n} . \mathrm{s}$ & $\mathrm{B}=1.78$ & $\mathrm{~B}=1.38$ \\
\hline & & $\mathrm{A} / \mathrm{B}=\mathrm{n} . \mathrm{s}$ & $\mathrm{A} / \mathrm{B}=\mathrm{n} . \mathrm{s}$. & $\mathrm{A} / \mathrm{B}=\mathrm{n} . \mathrm{s}$ \\
\hline & & $\mathrm{B} / \mathrm{A}=\mathrm{n} . \mathrm{s}$. & $\mathrm{B} / \mathrm{A}=\mathrm{n} . \mathrm{s}$. & $\mathrm{B} / \mathrm{A}=\mathrm{n} . \mathrm{s}$. \\
\hline
\end{tabular}

*see explanation for Table 1 
Table 3. Length of main shoot and width of the plant (cm), depending on the concentration of $\mathrm{GA}_{3}$ and the number of $\mathrm{GA}_{3}$ applications

\begin{tabular}{|c|c|c|c|}
\hline $\begin{array}{c}\text { Concentration } \\
\text { of } \mathrm{GA}_{3}(\mathrm{~A})\end{array}$ & $\begin{array}{c}\text { Number } \\
\text { of } \mathrm{GA}_{3} \text { ap- } \\
\text { plications (B) }\end{array}$ & $\begin{array}{l}\text { Length } \\
\text { of main } \\
\text { shoot }\end{array}$ & $\begin{array}{l}\text { Width } \\
\text { of the } \\
\text { plant }\end{array}$ \\
\hline \multirow{5}{*}{$250 \mathrm{mg}^{\cdot \mathrm{dm}^{-3}}$} & $\mathrm{C}^{*}$ & 29.4 & 16.5 \\
\hline & $1 \mathrm{x}$ & 30.8 & 14.4 \\
\hline & $2 \mathrm{x}$ & 32.7 & 14.6 \\
\hline & $3 x$ & 31.4 & 15.7 \\
\hline & mean for $\mathrm{A}$ & 31.1 & 15.3 \\
\hline \multirow{5}{*}{$500 \mathrm{mg}^{-\mathrm{dm}^{-3}}$} & $\mathrm{C}$ & 30.3 & 15.5 \\
\hline & $1 \mathrm{x}$ & 33.9 & 15.4 \\
\hline & $2 \mathrm{x}$ & 37.4 & 15.0 \\
\hline & $3 x$ & 34.6 & 16.3 \\
\hline & mean for $\mathrm{A}$ & 34.0 & 15.6 \\
\hline \multirow{4}{*}{ Mean for B } & $\mathrm{C}$ & 29.9 & 16.0 \\
\hline & $1 x$ & 32.3 & 14.9 \\
\hline & $2 \mathrm{x}$ & 35.1 & 14.8 \\
\hline & $3 x$ & 33.0 & 16.0 \\
\hline \multirow{4}{*}{\multicolumn{2}{|c|}{$\mathrm{LSD}_{0,05}$}} & $\mathrm{~A}=1.48$ & $A=$ n.s. \\
\hline & & $\mathrm{B}=2.80$ & $\mathrm{~B}=\mathrm{n} . \mathrm{s}$. \\
\hline & & $\mathrm{A} / \mathrm{B}=\mathrm{n} . \mathrm{s}$ & $\mathrm{A} / \mathrm{B}=\mathrm{n} . \mathrm{s}$ \\
\hline & & $\mathrm{B} / \mathrm{A}=\mathrm{n} . \mathrm{s}$. & $\mathrm{B} / \mathrm{A}=$ n.s. \\
\hline
\end{tabular}

*see explanation for Table 1

of September. In each combination, the inflorescence buds development to the microscopic stage took about four weeks. Buds were visible by naked eyes 7 to 10 days later. Irrespective of the concentration, the buds on the plants sprayed with $\mathrm{GA}_{3}$ twice developed slightly faster than in the control plants. Full flowering occurred at the beginning of November (Tables $1 \& 2$ ).

The application of $\mathrm{GA}_{3}$ at higher concentration resulted only in one-day prolongation of the cultivation period, whereas, irrespective of the concentration, the double spraying with $\mathrm{GA}_{3}$ shortened the growing period by two days, which was not observed in those sprayed once or three times (Table 2).

It was observed that both the concentration of $\mathrm{GA}_{3}$ and the number of its applications affected the length of main shoot. $\mathrm{GA}_{3}$ at higher concentration elongated them by only $3 \mathrm{~cm}$. However, irrespective of the concentration, the plants sprayed twice
Table 4. Length and width of the corymb $(\mathrm{cm})$, depending on the concentration of $\mathrm{GA}_{3}$ and the number of $\mathrm{GA}_{3}$ applications

\begin{tabular}{|c|c|c|c|}
\hline \multirow{2}{*}{$\begin{array}{c}\text { Concentration } \\
\text { of } \mathrm{GA}_{3}(\mathrm{~A})\end{array}$} & \multirow{2}{*}{$\begin{array}{c}\text { Number } \\
\text { of } \mathrm{GA}_{3} \text { ap- } \\
\text { plications } \\
\text { (B) }\end{array}$} & \multicolumn{2}{|c|}{ Corymb } \\
\hline & & length & width \\
\hline \multirow{5}{*}{$250 \mathrm{mg} \cdot \mathrm{dm}^{-3}$} & $\mathrm{C}^{*}$ & 12.0 & 9.0 \\
\hline & $1 \mathrm{x}$ & 9.2 & 6.8 \\
\hline & $2 \mathrm{x}$ & 9.4 & 6.6 \\
\hline & $3 x$ & 7.7 & 5.6 \\
\hline & mean for $\mathrm{A}$ & 9.6 & 7.0 \\
\hline \multirow{5}{*}{$500 \mathrm{mg} \mathrm{dm}^{-3}$} & $\mathrm{C}$ & 11.4 & 8.5 \\
\hline & $1 \mathrm{x}$ & 12.8 & 8.0 \\
\hline & $2 \mathrm{x}$ & 8.1 & 6.0 \\
\hline & $3 x$ & 10.5 & 6.9 \\
\hline & mean for $\mathrm{A}$ & 10.7 & 7.3 \\
\hline \multirow{4}{*}{ Mean for B } & $\mathrm{C}$ & 11.7 & 8.8 \\
\hline & $1 x$ & 11.0 & 7.4 \\
\hline & $2 \mathrm{x}$ & 8.7 & 6.3 \\
\hline & $3 x$ & 9.1 & 6.3 \\
\hline \multicolumn{2}{|c|}{$\mathrm{LSD}_{0.05}$} & $\begin{array}{c}\mathrm{A}=\text { n.s. } \\
\mathrm{B}=2.84 \\
\mathrm{~A} / \mathrm{B}=\mathrm{n} . \mathrm{s} . \\
\mathrm{B} / \mathrm{A}=\text { n.s. }\end{array}$ & $\begin{array}{c}\mathrm{A}=\mathrm{n} . \mathrm{s} . \\
\mathrm{B}=1.40 \\
\mathrm{~A} / \mathrm{B}=\mathrm{n} . \mathrm{s} . \\
\mathrm{B} / \mathrm{A}=\mathrm{n} . \mathrm{s} .\end{array}$ \\
\hline
\end{tabular}

*see explanation for Table 1

were longer (an average of 3 and $5 \mathrm{~cm}$ ) than those sprayed once or than the control. Neither the concentration nor the number of $\mathrm{GA}_{3}$ applications affected the width of the plants, which reached on average of $15.5 \mathrm{~cm}$. No significant differences in the interaction of both factors on the length of main shoots and the width of the plants were noted (Table 3).

Regardless of the number of $\mathrm{GA}_{3}$ application, the concentration did not affect the quality of inflorescences in the corymbs. The number of $\mathrm{GA}_{3}$ sprays, affected all those features, except for the number of peduncles and unstained buds. The corymbs produced by the control plants were longer than those sprayed two times with $\mathrm{GA}_{3}$. The plants treated with $\mathrm{GA}_{3}$ produced narrower corymbs but there were no significant differences in the width of the corymbs between single, double and triple $\mathrm{GA}_{3}$ application. Both at $250 \mathrm{mg} \cdot \mathrm{dm}^{-3}$ and at $500 \mathrm{mg} \cdot \mathrm{dm}^{-3} \mathrm{GA}_{3}$ concentration the plants produced similar number of unstained buds, buds 
at the early stages of flowering and inflorescences in full flowering. More inflorescences in full flowering and buds at the early stages of flowering were observed on the control plants. No significant interaction of both factors (the concentration and the number of $\mathrm{GA}_{3}$ applications) in terms of their effect on inflorescence quality was observed (Tables $4 \& 5)$.

Table 5. Number of peduncles, buds, and inflorescences in the corymb, depending on the concentration of $\mathrm{GA}_{3}$ and the number of $\mathrm{GA}_{3}$ applications

\begin{tabular}{|c|c|c|c|c|c|}
\hline \multirow[b]{2}{*}{$\begin{array}{c}\text { Concentration } \\
\text { of } \mathrm{GA}_{3}(\mathrm{~A})\end{array}$} & \multirow[b]{2}{*}{$\begin{array}{l}\text { Number of } \mathrm{GA}_{3} \\
\text { applications (B) }\end{array}$} & \multicolumn{4}{|c|}{ Corymb } \\
\hline & & peduncles & $\begin{array}{l}\text { unstained } \\
\text { buds }\end{array}$ & $\begin{array}{l}\text { buds in the } \\
\text { early stages } \\
\text { of flowering }\end{array}$ & $\begin{array}{l}\text { inflorescences } \\
\text { in full flowering }\end{array}$ \\
\hline \multirow{5}{*}{$250 \mathrm{mg}^{\cdot} \mathrm{dm}^{-3}$} & $\mathrm{C}^{*}$ & 12.5 & 12.1 & 9.1 & 32.7 \\
\hline & $1 x$ & 11.0 & 9.2 & 5.1 & 23.6 \\
\hline & $2 \mathrm{x}$ & 9.8 & 7.3 & 3.9 & 20.1 \\
\hline & $3 x$ & 9.1 & 10.8 & 3.8 & 18.9 \\
\hline & mean for $\mathrm{A}$ & 10.6 & 9.8 & 5.5 & 23.8 \\
\hline \multirow{5}{*}{$500 \mathrm{mg}^{-\mathrm{dm}^{-3}}$} & $\mathrm{C}$ & 11.2 & 10.2 & 10.6 & 28.6 \\
\hline & $1 \mathrm{x}$ & 10.1 & 10.7 & 6.5 & 23.8 \\
\hline & $2 \mathrm{x}$ & 8.8 & 8.2 & 4.8 & 18.4 \\
\hline & $3 x$ & 9.4 & 14.6 & 5.2 & 19.8 \\
\hline & mean for $\mathrm{A}$ & 9.9 & 10.9 & 6.8 & 22.6 \\
\hline \multirow{4}{*}{ Mean for B } & $\mathrm{C}$ & 11.8 & 11.2 & 9.8 & 30.7 \\
\hline & $1 x$ & 10.5 & 9.9 & 5.8 & 23.7 \\
\hline & $2 x$ & 9.3 & 7.8 & 4.3 & 19.2 \\
\hline & $3 x$ & 9.2 & 12.7 & 4.5 & 19.3 \\
\hline \multicolumn{2}{|c|}{$\operatorname{LSD}_{0.05}$} & $\begin{array}{c}\mathrm{A}=\mathrm{n} . \mathrm{s} . \\
\mathrm{B}=\mathrm{n} . \mathrm{s} . \\
\mathrm{A} / \mathrm{B}=\mathrm{n} . \mathrm{s} . \\
\mathrm{B} / \mathrm{A}=\mathrm{n} . \mathrm{s}\end{array}$ & $\begin{array}{c}\mathrm{A}=\text { n.s. } \\
\mathrm{B}=\mathrm{n} . \mathrm{s} . \\
\mathrm{A} / \mathrm{B}=\mathrm{n} . \mathrm{s} . \\
\mathrm{B} / \mathrm{A}=\mathrm{n} . \mathrm{s} .\end{array}$ & $\begin{array}{c}\mathrm{A}=\mathrm{n} . \mathrm{s} . \\
\mathrm{B}=3.96 \\
\mathrm{~A} / \mathrm{B}=\mathrm{n} . \mathrm{s} . \\
\mathrm{B} / \mathrm{A}=\mathrm{n} . \mathrm{s} .\end{array}$ & $\begin{array}{c}\mathrm{A}=\text { n.s. } \\
\mathrm{B}=6.80 \\
\mathrm{~A} / \mathrm{B}=\text { n.s. } \\
\mathrm{B} / \mathrm{A}=\text { n.s. }\end{array}$ \\
\hline
\end{tabular}

*see explanation for Table 1

\section{DISCUSSION}

Treatments with gibberellin can trigger flowering in some plants, in others the effect can be the opposite (Mutasa-Göttgens and Hedden 2009). In the experiment presented here, $100 \%$ of the plants flowered irrespective of the $\mathrm{GA}_{3}$ concentration and the number of sprays applied. At each application, bud development to the microscopic stage took about four weeks. On the plants sprayed with $\mathrm{GA}_{3}$ twice, the buds developed slightly faster than on the control plants. The application $\mathrm{GA}_{3}$ at higher concentration resulted only in one-day prolongation of the growing period. Full flowering occurred at the beginning of November. This time of flowering coincided with All Saints Day in Poland when, by tradition, chrysanthemums are bought in huge numbers and ajania can become an interesting alternative of chrysanthemum, mostly as an additive to the flower arrangements. In the experiment reported by Dobrowolska and Janicka (2007), GA application at concentration of $10 \mathrm{mg} \cdot \mathrm{dm}^{-3} \mathrm{did}$ not accelerate flowering of Impatiens hawkeri 'Riviera Deep Salmon' and 'Riviera Pink', but it increased the number of flowers in 'Riviera Pink'. SchroeterZakrzewska and Janowska (2007) reported that application of $\mathrm{GA}_{3}$ increased number of buds and flowers in Impatiens walleriana, but had not impact on the time of flowering. In the research presented, concentration of $\mathrm{GA}_{3}$ did not affect the quality of plants (length and width of the corymb, the number of peduncles, unstained buds, buds at the early stages of flowering, and inflorescences in full flowering) regardless of the number of applica- 
tions. The number of $\mathrm{GA}_{3}$ sprays, however, affected all features that determine the quality of corymbs, except the number of peduncles and unstained buds. The plants treated with $\mathrm{GA}_{3}$ produced narrower corymbs and the double spray resulted in their shortening. Pobudkiewicz and Nowak (1992) showed that the application of gibberellic acid only slightly elongated the peduncles of Gerbera jamesonii 'Amber' but not 'Queen Rebecca', $\mathrm{GA}_{3}$ increased the inflorescences diameter but shortened vase life. $\mathrm{GA}_{3}$ enhanced the postharvest longevity of Zantedeschia alliottiana cv. 'Black Magic' flowers (Janowska and Jerzy 2004) and leaves (Janowska and Jerzy 2003a, b). The reaction of chrysanthemums to the treatment with gibberellic acid may vary depending on genotype (Schmidt et al. 2003; Vieira et al. 2011a, b). In 'Yoko Ono' and 'Faroe', irrespective of the time and dose of $\mathrm{GA}_{3}$, no changes in the length of the plants were observed (Vieira et al. 2011a, b). However in 'Viking' increase of shoots' elongation by almost $17 \%$ has been observed, compared with the control plants (Schmidt et al. 2003). As reported by Zalewska et al. (2008) in cascade-like cultivars of chrysanthemum a significant effect of $\mathrm{GA}_{3}$ on the length of shoots of flowering plants was noted only in 'Dali' cv. although at the first stage of glasshouse growing 'Rubens' also reacted to $\mathrm{GA}_{3}$ with a shoot elongation. In the experiments of above authors the plants were treated three times with $\mathrm{GA}_{3}$ at concentration of $450 \mathrm{mg} \cdot \mathrm{dm}^{-3}$, starting from the $9^{\text {th }}$ week of growth. The effect of $\mathrm{GA}_{3}$ on the plant growth is more distinct when the application takes place at earlier stages of plant development. This has been shown by Schmidt et al. (2003) who demonstrated that $\mathrm{GA}_{3}$ application in the $2^{\text {nd }}$ or $4^{\text {th }}$ week after planting increased length of branches, as compared to the applications in the $8^{\text {th }}$ or $10^{\text {th }}$ week. According to Grzesik (1989), the time of $\mathrm{GA}_{3}$ application can be more important than the concentration. In our experiment the plants were sprayed with $\mathrm{GA}_{3}$ during the vegetative growth, starting from the $5^{\text {th }}$ week of growth (once, twice or three times) over 3 weeks. Both the concentration and the number of sprays affected the length of main shoots, but more spectacular effect was expected.
The present study showed that exogenous application of $\mathrm{GA}_{3}$ at concentrations, time and number of treatments investigated only slightly affected the growth and development of Ajania pacifica. This indicates a specificity of the response of this plant to $\mathrm{GA}_{3}$ treatment, which appears to be different from other ornamental species. Perhaps this is cultivar specificity and other cultivars of this species would react differently, so obtained results call for further studies, using other cultivars, but also different $\mathrm{GA}_{3}$ concentrations or terms of treatments.

\section{CONCLUSIONS}

1. Double application with $\mathrm{GA}_{3}$ accelerated flower bud development of Ajania pacifica, thus shortened the cultivation time by about two days.

2. $\mathrm{GA}_{3}$ at concentration of $500 \mathrm{mg} \cdot \mathrm{dm}^{-3}$ stimulated the elongation more than $250 \mathrm{mg} \cdot \mathrm{dm}^{-3}$; the plants sprayed twice were longer than those, which were sprayed once and non-sprayed. Elongation of shoots, was however not important, and corymbs were shorter and narrower, containing less inflorescences. Both $\mathrm{GA}_{3}$ concentration and the number of applications did not have any effect on the width of the plants.

3. Exogenous application of $\mathrm{GA}_{3}$ at concentrations, time and number of treatments used only slightly affected the growth and development of Ajania pacifica 'Bea'. Perhaps other cultivars of this species would react differently, so obtained results call for further studies.

\section{REFERENCES}

Dobrowolska A., Janicka D. 2007. The effect of growth regulators on flowering and decorative value of Impatiens hawkeri W. Bull belonging to Riviera group. Rocz. AR Pozn., Ogrodn. 41: 35-39. [in Polish with English abstract]

Erhardt W., Götz E., Bödeker N., Seybold S. 2008. Zander. Handwörterbuch der Pflanzennamen. 18 Auflage, Eugen Ulmer KG, Stuttgart, p. 142.

Grzesik M. 1989. Factors influencing the effectiveness of growth regulators in nursery production. Acta Hort. 251: 371-375. 
Hong-Bo Z., Fa-Di Ch., Su-Mei Ch., Guo-Sheng W., Wei-Ming G. 2010. Molecular phylogeny of Chrysanthemum, Ajania and its allies (Anthemideae, Asteraceae) as inferred from nuclear ribosomal ITS and chloroplast trnL-F IGS sequences. Plant Syst. Evol. 284: 153-169.

Janowska B., Jerzy M. 2004. Effect of gibberellic acid on the post-harvest flower longevity of Zantedeschia alliottiana (W. Wats) Engl. Acta Sci. Pol., Hortorum Cultus 3(1): 3-9.

Janowska B., Jerzy M. 2003a. Effect of gibberellic acid on the quality of cut leaves of Zantedeschia alliottiana /W. Wats/ Engl. Acta Sci. Pol., Hortorum Cultus 2(1): 85-94. [in Polish with English abstract]

Janowska B., Jerzy M. 2003b. Effect of gibberellic acid on the post-harvest leaf longevity of Zantedeschia alliottiana (W. Wats) Engl. J. Fruit Ornam. Plant Res. 11: 69-76.

Meng J.C., Hu Y.F., Chen J.H., Tan R.X. 2001. Antifungal highly oxygenated guaianolides and other constituents from Ajania fruticulosa. Phytochemistry 58: 1141-1145.

Mutasa-Göttgens E., Hedden P. 2009. Gibberellin as a factor in floral regulatory networks. J. Exp. Bot. 60(7): 1979-1989.

Pobudkiewicz A., Nowak J. 1992. The effect of gibberellic acid on growth and flowering of Gerbera jamesonii Bolus. Folia Hort. 4/2: 35-42.

Rudnicki F. 2011. FR-ANALWAR software based on Microsoft Excel, Bydgoszcz.

Schmidt C., Bellé A.B., Nardi C., Toledo A.K. 2003. The gibberellic acid $\left(\mathrm{GA}_{3}\right)$ in the cut chrysanthe- mum (Dedranthema grandiflora Tzevelev.) 'Viking': planting summer/autumn. Ciência Rural, Santa Maria 33(2): 267-274.

Schroeter-Zakrzewska A., Janowska B. 2007. The effect of gibberellic acid on growth and flowering of $\mathrm{Im}$ patiens walleriana Hook. from the Spellbound group. Rocz. AR Poznań, Ogrodnictwo 41: 195200. [in Polish with English abstract]

Vieira M.R.S., Souza A.V., Santos C.M.G., Alves L.S., Cerqueira R.C., Paes R.A., Souza A.D., Fernandes L.M.S. 2011a. Stem diameter and height of chrysanthemum cv. Yoko Ono as affected by gibberellic acid. Afr. J. Biotechnol. 10(56): 11943-11947.

Vieira M.R.S., Lima G.P.P., Souza A.V., Costa P.N., Santos C.M.G., Alves L.S., Oliveira N.G. 2011 b. Effect of gibberellic acid on the quality of chrysanthemum (Dendranthema grandiflora L.) cv. Faroe. Afr. J. Biotechnol. 10(71): 15933-15937.

Zhao H., Chen F., Fang W., Guo W., Xie W. 2008. Creating novel germplasms of Chrysanthemum by employing the Ajania pacifica. Sci. Agric. Sinica 41(7): 2077-2084. [in Chinese with English abstract]

Zalewska M., Żabicka A., Wojciechowska I. 2008. The influence of gibberellic acid on the growth and flowering of cascade chrysanthemum cultivars in outside glasshouse. Zesz. Probl. Post. Nauk Roln. 525: 525-533. [in Polish with English abstract]

Zalewska M., Antkowiak M., Tymoszuk A. 2012. Micropropagation of Ajania pacifica /Nakai/ Bremer et Humphries with single-node method. Nauka Przyr. Technol. 6, 1, 310 . 